\title{
Challenges facing financial engineering with Islamic rules
}

\author{
Khalaf Al-Taani \\ Finance \& Banking Dept, Irbid National University, Irbid, Jordan
}

\section{Email address:}

ktaani@yahoo.com

\section{To cite this article:}

Khalaf Al-Taani. Challenges Facing Financial Engineering with Islamic Rules. International Journal of Economics, Finance and Management Sciences. Vol. 1, No. 5, 2013, pp. 234-240. doi: 10.11648/j.ijefm.20130105.14

\begin{abstract}
Despite their importance in financial sector development, derivatives are still not generally accepted as legitimate products in Islamic finance. Conventional derivatives and the world of Islamic financial products has chasm between each other as they have different approaches in important issues like interest and ambiguity. While recent events in the world economy have sparked a global debate on derivatives and the damage caused by them, strict Sharia rules saved Islamic finance institutions from the worst of the crisis. On the other hand, due to lack of sufficient instruments for protection against volatility in currency, interest rate and commodity prices, the ability of Islamic finance institutions to survive future shocks is in question. As the Islamic banks are struggling to develop hedging tools with regard to doubt on their usage cased by religious differences, this article explores the validity of derivatives in accordance with basic legal principles of the Sharia and summarizes the key objections of scholars that challenge the permissibility of derivatives under Islamic law. In conclusion, the article delivers suggestions for Sharia compliance of derivatives .
\end{abstract}

Keywords: Islamic Finance, Financial Engineering, Derivatives

\section{Introduction}

The global financial crisis has shaken the financial system around the world Owing to its impetus it has been labeled as the worst crisis since the Great Depression. It is now crystal clear that the current structure of financial system is not stable and the invisible hand is not doing what its proponents claimed.

The long period of moderation together with easy money, uncontrolled growth of credit and debt, regulation and regulator slacken off, mismanagement of risks, lack of transparency, high leverage, and lack of external and internal audit - among other factors- are thought to be the main causes of the crisis. Whatever founded as new culprits for crisis; these will be the echo of greed which exists inside human beings. Although every philosopher and scholar believes that greed is diabolic, one must admit that it is one of the main motivations of developing civilization for humans. So greed could be seen as the dilemma of modern capitalist economy as it is the main motivation of economic growth and the main reason for economic collapse. Eventually, when financiers, bankers, investors, politicians and regulators forget the basic definition of economics written by J. M. Keynes "Economics is essentially a moral science and not a natural science." conventional financial markets collapse.
While there are many debates on restructuring and regulating national economies and financial markets, it is strongly argued that Islamic finance - has the potential to become an alternative model for a global system \| (Kayed, Hassan, 2011, Aglionby, 2009; Ayub, 2007; Chapra, 2009; Özturk, 2008; Rafique, 2008; Vandore, 2008). These commentators introduce Islamic finance as a possible alternative system which eliminates greed with rules of Sharia. They indicate that remaining relatively positive in the midst of the crisis, being able to stay steady against its implications and, eventually emerging as a more equitable and efficient system, have raised the profile of Islamic finance. This contention is backed up by growth data of Islamic finance.

When many of the financial systems found themselves deleveraging amid the capital market dislocation and its spread to economies around the globe, Islamic finance stayed strong in 2009 and 2010 (Standard \& Poor's, 2010). According to publicly available information, assets of the top 500 Islamic banks expanded $28.6 \%$ to total $\$ 822$ billion in 2009, compared with $\$ 639$ billion in 2008 .

Furthermore, there is no doubt that strict Sharia rules saved Islamic finance institutions from the worst of the crisis, but Islamic finance institutions are not totally immune to the crisis; they had felt the hit as well, although to a much more moderate extent. Due to lack of sufficient 
instruments for protection against volatility in currency, interest rate and commodity prices, the ability of Islamic finance institutions to survive future shocks and Islamic solution to global financial crisis will be always arguable.

Despite the promising values of Islamic finance and availability of new Islamic financial instruments, the argument of potential to become an alternative model for the global system would always be overshadowed by the absence of generally accepted Sharia compliant derivatives and other hedge instruments. Derivatives play an important role in financial sector development, however, they are still not generally accepted legitimate products in Islamic finance. There is a chasm between conventional derivatives and Islamic financial products as they have different approaches to several important issues like interest or ambiguity. Islamic finance can synthesize close equivalents to equity and debt base instruments, but there have been difficulties in developing Sharia complaint derivatives.

This article explores the validity of derivatives in accordance with basic legal principles of the Sharia and summarizes the key objections of scholars regarding the permissibility of derivatives under Islamic law. In conclusion, the article delivers suggestions for Sharia compliance of derivatives and Turkish Derivatives Exchange futures contracts.

\section{Financial Engineering in Islamic Finance}

The conventional financial engineering adapts existing financial instruments to today's financial markets or designs new instruments. When it comes to Islamic finance, financial engineering gains a special feature which can be described clearly as designing and innovating without violating any of the conditions defined by the Islamic law or Sharia. Rules of Sharia that identifies whether financial engineering depart from Sharia will be the narrow rope for heaven waiting opposite side.

Concept of Sharia could be inscrutable for many nonMuslims due to its sui generis extent. Sharia is not only governs the relationship between man and God but also relationships among mankind. A devoted Muslim must always be sure that actions of him are Sharia compliant. The primary sources of the Sharia are (a) the Quran, (b) the sunnah (the practices, writings, pronouncements and examples of the Prophet Muhammad (SAV)), (c) ijma' (consensus, particularly the consensus of the community of scholars or the -assembly of the learned II ), and (d) qiyas (or analogical deductions and reasoning). The application of the Sharia to commercial and financial activities, and thus the practical elucidation of it, is effected by Islamic scholars due to demand from Muslims. The Islamic jurisprudence $\left(\right.$ Fiqh $^{1}$ ) expanded Islamic law (based directly

\footnotetext{
${ }^{1}$ Fiqh is an expansion of the code of conduct (Sharia) expounded in the Quran, often supplemented by tradition (Sunnah) and implemented by the rulings and interpretations of Islamic jurists. Fiqh deals with the
}

on the Quran and Sunnah) with evolving rulings/interpretations of Islamic jurists who are subscribed to different schools of Islamic jurisprudence.In some cases these schools apply varying interpretations to identical factual situations and to a certain extent, may arrive at somewhat different conclusions under the case by case methodology of Islamic Law. As a result, Sharia scholars and the boards on which they sit play a highly influential role in Muslim life generally and in Islamic finance particularly.

Although the main principle of Islamic finance is -risksharing \| there are major prohibitions of Sharia associated with financial life. These prohibitions are the main pillars of Islamic finance and can be explained briefly as;

a) Prohibition of Riba: Islam prohibits all forms of riba which has been understood throughout Muslim history as being equivalent to interest paid on a loan.

b) Prohibition of Gharar: Defined as to knowingly expose oneself or one's property to jeopardy, or the sale of a probable item whose existence or characteristics are not certain (Schoon, 2008). Gharar has been one of the most difficult Islamic juristic terms to understand. In essence gharar refers to acts and conditions in a contract, the full implications of which are not clearly known to the parties. Which appears to be very similar to - asymmetric information \| (Munawar, Khan 2005). All kind of fraud, cheating and dishonesty also covered by prohibition of gharar.

c) Prohibition of Maysir: Islam prohibits all kinds of gambling and games of chance. In financial aspect when there is a possibility of total loss for one party, it's clear that there is presence of maysir (gambling).

d) Prohibition of Certain Economic Sectors: Financing of industries deemed unlawful by Sharia--such as pork, entertainment and gambling - is forbidden.

In addition to these major prohibitions which can be found in Qur'an, Islamic scholars state terms of financial contracts using large number of hadiths ${ }^{2}$ and other sources of Islam. For instance, an authentic hadith "Do not sell what is not with you" is another important rule of Sharia in Islamic finance. Most of Islamic scholars agree that someone is not allowed to sell something unless he owns it or its constructive possession. As might have been expected this hadith has a great importance on futures and other kinds of derivatives.

Consequently financial engineering in Islamic finance requires a close collaboration with Islamic scholars of fiqh. Unfortunately as Vikor (2005) states in his comprehensive study; "There is not just one Islamic law. There are many different Islamic laws and different schools, time period and countries.". Considering this fact, every contract and

\footnotetext{
observance of rituals, morals and social legislation in Islam.

${ }^{2}$ The term hadith is used to denote a saying, act or tacit approval, validly or invalidly, ascribed to the prophet Muhammad (SAV). Hadith are regarded by traditional Islamic schools of jurisprudence as important tools for understanding the Qur'an and in matters of jurisprudence.
} 
financial instrument designed with an -Islamic || label and got approval from an Islamic scholar will be at risk of being stamped as haram (unlawful) by another Islamic scholar. This issue must be left to scholars and financial engineers must concentrate on the basic prohibitions while designing products as long as prominent Islamic scholars declare that the product do not violate basic prohibitions of Islam.

So far, Islamic financial products have essentially been limited to classical modes that developed centuries ago or similar ones adapted to modern conditions. Almost being non-existent 30 years ago, modern Islamic finance has risen to become a trillion dollar industry, and has engineered many different instruments (Clarke, 2009). While financial markets are becoming more and more sophisticated, and competitive, financial engineering and innovation are becoming more imperative in Islamic finance. If the needs are genuine, then the innovative instruments could either be adapted from conventional menu, or new Sharia compatible alternatives could be invented (Munawar, Khan 2005). This process must, however, take into consideration of rules outlined above and every contract or financial instrument must be analyzed for approval of scholars whether it is Sharia compliant.

Islamic scholars agree that hedging in order to reduce risk or protect investment allowed in Islam, however the conventional derivative instruments of forwards, futures, swaps and options in the present form are not considered as Sharia complaint (Mohamad, Tabatabaei 2008). Obiyatullah Ismath Bacha (1999) stated in his extensive review that, some of the Islamic instruments that are similar to derivatives and the objection of Islamic scholars regarding derivatives might need some rethinking and evaluation. But why scholars have disputed the permissibility of derivatives trading in Islamic law? And do all scholars dispute derivatives in Islamic finance?

Due to length constraint of this article it will be wise to analyze this issue on the example of futures contracts. But findings can be expanded to other instruments like forwards, options etc. The futures contract, which is the fundamental instrument of the organized market, is a bilateral contract between two parties that allows one party, the seller, to sell a particular reference asset at a forward price for settlement at a future date, and second part, the buyer, to purchase the reference asset at a forward price on the named date. Futures contracts appear to be identical to forward contracts. However as a result of the exchange mechanism, the futures positions calls for a daily settlement of cash flows, rather than a single settlement of cash flows at maturity: each futures position is revalued by clearing house at close of each day, and net settlement is made in favor of the party holding the day's gain (Banks, 2006).

Islamic scholars who disputed the permissibility of futures trading in Islamic law have highlighted the following five points in their critique (Kamali, 2005).

1. Futures sales proceed over goods that are not existent at the time of contract; no goods are delivered at the time and no price is paid.

2. Futures consist of short selling, in which the seller does not own or possess the item he sells.

3. Futures sales fall short meeting the requirements of qabd or taking possession of the item to resale. Nearly all sales and purchases in the futures market take place without physical delivery.

4. Deferment of both counter-values to a future date turns futures sales into the forbidden sale of one debt for another (bay'al-kalī bil-kalì).

5. Futures trading involve speculation that verges on gambling and gharar.

When these critiques are given once over; it is presumably noticeable that the first four points are premised on theoretical fiqhi positions on conventional sale and ignores the operational procedures of futures. On the other hand, the critique about involving of gambling and gharar seems to set aside the efficiency of futures markets to reduce price volatility and destabilizing the spot market (Kamali, 2005).

While Mufti Taqi Usmani, a prominent Islamic scholar argued that the use of futures (Dali, Ahmad, 2006) due to deferment of money and commodity delivery and the excessive involvement of speculation is prohibited according to Sharia, another group of scholars pointed out that commodity futures could be Sharia complaint with some adjustments (Salehabadi, Aram 2002, Obiyatullah, 1999 Obaidullah 2001, Kamali, 2005, Bayındır 2009).

But there is no consensus on these - adjustments $\|$. Despite the ambiguity about how to comply these instruments to Sharia, there is a unanimity of opinion on the - need I| for Sharia-complaint derivatives.

As stated before, Islamic finance does not provide an effective risk management mechanism for Islamic institutions. Volatility of prices and currencies is a modern phenomenon which scholastic figh has not specifically addressed (Kamali, 2005). But it is clear that Islamic financial institutions are in need to manage risk, not only in terms of the institutions own risk but also to create products that allow their customers to do the same, for instance, in order to reduce an individual's or corporation's exposure to currency and other risks. Developing Sharia complaint hedging instruments is crucial for Islamic institutions and Islamic mutual funds, particularly those that invest globally and need to manage various types of risk exposures. It would promote Islamic cross-border business deals and investment flows. It would additionally increase the trading volume and liquidity of Islamic securities thus reducing transaction costs and rendering Islamic capital markets less risky and more attractive (Ghoul, 2008).

So financial engineers are now facing both an exciting opportunity and an interesting challenge, namely to produce products which provide parties with the unquestioned benefits of conventional derivatives (particularly with respect to effective hedging and general risk management) whilst also respecting the core tenets of Sharia (Uberoi and Evans, 2008). 


\section{Sharia Compliant Derivatives}

How can a derivative be Sharia-compliant? Jobst (2008) stated that futures and options may be compatible with Islamic law if they;

i. are employed to address genuine hedging demand on asset performance associated with direct ownership interest,

ii. disavow mutual deferment without actual asset transfer,

iii. eschew avertable uncertainty (gharar) as prohibited sinful activity (haram) in a bid to create an equitable system of distributive justice in consideration of public interest (maslaha ${ }^{3}$ ).

Considering the above tenets, purposes of transactions and relative motivations of parties would also be significant along with structuring and return profile of a transaction for Sharia scholars and financial engineers.

Certainly, the implementation of Sharia in the area of derivatives remains varied and there is continued debate and concern, surrounding derivative transactions due to varying interpretation of Sharia by the different schools. The use of Islamic derivative transactions has been readily accepted in Malaysia In March of 2010, after years of effort, the International Swaps and Derivatives Association (ISDA) and International Islamic Financial Market (IIFM) released the 2010 - Tahawwut ${ }^{4}$ Master Agreement \| for the standardized effectuation of certain swaps and derivative transactions for OTC markets that are compliant with the principles of Sharia. While majority of Middle East based Islamic finance institutions prefers to stay in -evaluation $\|$ phase.

Presence of legal uncertainty on derivative transactions in Islamic finance entail procedural and substantive difficulties. The absence of practical and hardwired guidance on Sharia compliance affects the legal integrity and restitution interest of parties to derivative transactions. Islamic jurisprudence is not definite or bound by precedent and still lacks of homogeneous interpretation and universal recognition. Legal opinions of Islamic courts may deviate from previous decisions made by other Sharia scholars (Alsayyed, 2009).

Although these debates continue on the Islamic scholar's side, Islamic finance practitioners already uses a number of structured products that believed to be complaint to Sharia; such as Islamic profit rate swap, Islamic profit rate option, Islamic cross currency swap, Islamic FX swap. And they found out some old contracts from history which can be used for hedging. To understand the concept of Sharia complaint financial derivative contracts, a short summary about these products is included in the section below;

\footnotetext{
${ }^{3}$ Arabic term Maslaha (means - public interest $\|$ ) is a concept in traditional Islamic Law. It is invoked to prohibit or permit something on the basis of whether or not it serves the public's benefit or welfare. The concept is related to that of Istislah. While the meaning of maslaha is 'public interest', the meaning of istislah is 'to seek the best public interest'. ${ }^{4}$ Tahawwut: Hedging in Arabic
}

a) Bai-Salam Contract: Bai Salam is a form of forward contract when the price for an asset is paid upfront at the time of the contract for an asset or commodity to be delivered later. In Arabic, the word bai means sale, salam means delivery. The seller undertakes to supply some specific goods to the buyer at a future date in exchange of an advance price fully paid at the time of contract. According to normal rules of the Sharia, no sale can be affected unless the goods are in existence at the time of the bargain, but Salam sale forms an exception given by the Holy Prophet himself to the general rule provided the goods are defined and the date of delivery is fixed. It is necessary that the quality of the commodity intended to be purchased is fully specified leaving no ambiguity leading to dispute. It has the following features:

- $\quad$ One end of the contract must be settled on the spot.

- It is the seller's obligation that is deferred to a future date; thus the underlying commodity must be delivered at maturity.

b) Bai-Urbun Contract: n Arabic, the word urbun means a down-payment or a deposit for a future transaction. Bai-urbun can be used as a Sharia-complaint alternative to options. It is a deposit given by the buyer to the seller in a buying and selling contract. If the sale proceeds, the deposit will be part of the price of the goods. Otherwise, it will be considered as hibah (gift) from the buyer to the seller.

A similarity exists between a call option and BaiUrbun in the sense that buyer loses the advance payment if he does not execute the transaction. In the case of a call option, the option premium is lost, even if the option is exercised and the contract is confirmed. It is worth mentioning that not all Islamic scholars find Bai-Urbun acceptable.

c) Cross Currency Swap: In order to make swap transactions Sharia complaint two simultaneous murabaha transactions, a term and reverse murabaha, are used to generate cash flows similar to a conventional currency swap. A murabaha is a sale arrangement whereby financier purchases goods from a supplier and then on-sells them to a counterparty at a deferred price that is marked-up to include the financier's profit margin. This profit margin is deemed justified since the financier takes title to the goods, albeit possibly only briefly, and hence accepts the commercial risk of their ownership.

d) Profit Rate Swap: The Profit Rate Swap seeks to achieve Sharia-compliance by using reciprocal murabaha transactions: commercial arrangements long accepted by Sharia scholars. The parties enter into murabaha contracts to sell Sharia-compliant assets (often London Metal Exchange traded metals) to each other for immediate delivery but on deferred payment terms. A term murabaha is used to generate fixed payments (comprising both a cost price and a fixed profit element) and a series of corresponding reverse 
murabaha contracts are used to generate the floating leg payments (the cost price element under these reverse murabaha contracts is fixed but the profit element is floating, as further explained below). This structure, in effect, is not dissimilar to the "parallel loans" structure that was used by institutions in the earliest examples of conventional swap transactions.

There is a couple of other products that can be used as a derivative (if engineered carefully) such as Bai-Muajjal (Deferred payment of goods which are delivered upfront) and Bai Istisna (Payment upfront or in sages for manufacture and/or delivery of goods in future involving long-term positions).

On the other hand, a promising instrument —Wa'ad I has started a debate among Islamic scholars, as more and more financiers look to these contracts with sympathy. Wa'ad is a traditional Islamic product and the term occurs frequently in the Qur'an. While it can mean "to promise", "to pledge" or "to firmly intend", in the context of commercial dealings, it is generally accepted that a wa'ad means a unilateral promise. It is this unilateral nature of the wa'ad that potentially makes it a very useful and flexible tool in structuring Sharia-compliant transactions. Nonetheless, since it is a promise and not a contract, it does not violate Sharia prohibitions on conventional forward- or short-selling. This structure ends with the guaranteeing a purchase of shares or securities at a nominal value. The purchase and sale transactions are still — spot" deals, hence becoming less of a Sharia issue.

Despite the complicated view of Sharia complaint derivatives topic, when there is a real need solutions are getting simple. For instance even the Sharia compliance of futures was still a controversial issue in 1997. Shariah Advisory Council of the Securities Commission of Malaysia (SAC) resolved that the futures contract on crude palm oil is admissible as it is in accordance with Shariah principles in 1998. On the other hand, in a discussion on composite index futures contract, the SAC passed a resolution permitting bai-urbun from the Islamic jurisprudence perspective. More challenging, the SAC resolved that the mechanism for stock index futures contracts does not contradict Sharia principles. Therefore, stock index trading is allowed by SAC in 1998 as long as it is Sharia compliant, and this is done by ensuring that the index component is made up of Sharia compliant securities (Securities Commission, 2007).

\section{Conclusion}

The heterogeneity of scholastic opinion about the Sharia compliance of any financial product is the main difficulty of working in Islamic finance field. Although it's quite challenging, it provides great opportunities for financial engineers, especially in Islamic product engineering. While Islamic finance supporters have come to realize the numerous benefits of derivative markets, the western financiers who had been hit by derivative markets take cognizance of Islamic finance. Although it seems to be a dilemma, in remote future, world will witness an Islamic finance structure with derivative markets, and a conventional financial market whose derivative markets are re-structured with inspiration from certain principles of Islamic finance.

Pioneers of Islamic finance are aware of risk diversification through derivatives that improves stability at all levels of the financial system and enhances total welfare. There is general consensus on derivatives capability for continuous price formation, enhance liquidity management and supplement cash markets at lower funding cost. But the absence of generally accepted derivative products deprives financial institutions of this array of these advantages. Furthermore this absence undermines the new vision of - becoming an alternative model for global financial system \| for Islamic finance. Although there are many challenges in front of Islamic derivatives markets such as viability and diversification, and competition with highly sophisticated and competitive international market, the biggest challenge still stands without any advance: compliance to Sharia. The absence of practical and hardwired guidance on Sharia compliance affects the legal integrity and investor confidence. Islamic jurisprudence is not define or bound by precedent and still lacks of homogeneous interpretation and universal recognition (Jobst, 2008).

Although SAC in Malaysia resolved that the futures contract on certain commodities and stock index futures contracts is permissible as it is in accordance with Shariah principles, there are still inconsistency of legal opinions which raises doubts about general permissibility of derivative instruments in Islamic finance.

While there are large number of financial instruments categorized under derivatives, futures contracts are promising the brightest future in Islamic finance. Derived from commodities, futures contracts can be used as hedging devices, effective planning tools, risk management and risk reduction within the broad scope of public interest (maslaha) which is recognized basis of judgment in Sharia. Beside these features futures contracts, has advantageous over other derivatives, on the basis of basic prohibitions of Sharia.

First of all, futures contracts are clear of riba, as sales and purchases therein do not involve payment of interest by any of the parties involved except unacceptable interest rate futures. The only money that is deposited is the margin which is kept in the customer's own account and is returned to him when not needed. The guarantee of clearing house or exchange for the contracting parties meets their obligations according to the terms of their agreement featured by futures contracts is an unprecedented gharar-prevention measure. Since this guarantee is 100 percent, there is no room for gharar on account of the parties' failure to meet their obligations.

These unique features make futures (and even exchange traded options) contracts, an ideal candidate for becoming a 
basis for generally accepted Sharia-complaint derivative instrument.

The first step for designing a Sharia complaint contract starts with eliminating gharar issue with standardization of contracts and eliminating counterparty default risk. To eliminate any uncertainty over a contract, they must be traded on exchanges as standardized contracts such as futures. While there are attempts to standardize global framework for setting basic terms for Sharia complaint hedging transaction on over the counter markets such as ISDA-IIFM 2010 Tahawwut Master Agreement still do not give rise to an actual transaction. The parties must enter into additional agreements for a real transaction (Fagerer, Pikiel, and McMillen, 2010). So this standardized agreement just gives a framework for contract and real contract will be discussed later in order to make the whole transaction vulnerable from gharar side. Using standardized futures contracts that eliminate any contractual uncertainty, will also eliminate any counterparty and default risk. with existence of exchange or clearing house guarantee.

As second step market segmentation will be a radical transformation in exchange structure for eliminating any speculative acts, gambling and short selling. If futures exchanges create a special market for only Islamic finance institution's participation, speculation and short selling would be excluded from market. The fundamental basis of this assertion depends pre-assumption of Islamic institutions and their customers' faith based acts. As Islamic financial institutions monitors their customers more carefully than conventional interest based banks, due to their specialized lending practices, they have ability to choose customers for futures contract. With this self control system, futures can only be offered to customers who have an underlying asset to hedge like as a customer with murabaha dealing with an Islamic bank on live cattle. Meanwhile if a customer has no trading activities relevant with cotton, his participation in cotton futures market will obviously a speculative act. And Islamic banks must avert this kind of customers to participate in this market for maslaha. While this step would cause a lack of liquidity in market, it is clear that an illiquid market with a possibility of having future liquidity is better than no market.

Third step will be determination of contract settlement method as physical settlement. This last step will eliminate many of arguable features of futures contracts, but it would raise questions among financiers whether these contracts are really financial contracts. This would restrict the futures market development, however, would also prevent individual interpretations of many scholars.

While world economy transforms with globalization, modern commerce has become a global connection business with old risk and new paradigms. Today, risks in commerce are dependent from your field of activity. As risks are changing, modern financial markets have witnessed a large number of new and unprecedented instruments of risk diversification and hedging that were not known in earlier times. Hedging risks like currency or commodity price, has a significant role in promoting trade. Therefore, to encourage and secure Muslims' participation in the wealth created by commerce, Islamic finance should introduce proper hedging instruments.

\section{References}

[1] Aglionby, J. (2009). Islamic banks urged to show the way. Financial Times. Retrieved from $\mathrm{http}: / / w w w . f t . c o m /$ world/economy

[2] Alsayyed, N. (2009), Shari'ah Parameters of Islamic Derivatives in Islamic Bankingand Finance, Available on line at http://www.kantakji.com/fiqh/Files/Finance/N362.pdf

[3] Ayub, M. (2007). Understanding Islamic finance. Hoboken, NJ: Wiley.

[4] Banks, E. (2006), Synthetic and Structured Assets, New Jersey, John Wiley \& Sons.

[5] Clarke, R., (2009) Islamic Banking, the OECD Observer, Nov 2009.

[6] Chapra, U. (2009). The global financial crisis: Can Islamic finance help? Retrieved from http://www.newhorizonislamicbanking.com

[7] Fagerer, R, Pikiel, M.E. and McMillen, M.J.T., (2010) The 2010 Tahawwut Master Agreement: Paving the Way for Shari'ah-Compliant Hedging. Available at SSRN: http://ssrn.com/abstract $=1670118$

[8] Ghoul, W., (2008) Risk Management and Islamic Finance: Never the Twain Shall Meet? Journal of Investing; fall 2008; 17,3

[9] Jobst, A. A. (2008), Derivatives in Islamic Finance, in Islamic Capital Markets: Products, Regulation and Development (Ali, S.S. ed), Islamic Development Bank.

[10] Kamali, M. H. (2005), Fiqhī Issues in Commodity Futures. in Financial Engineering And Islamic Contracts 20-43 (Iqbal, Munawar \& Tariqullah Khan, eds.), Palgrave Macmillan.

[11] Kayed, R. N. and Hassan, M. K. (2011), The Global Financial Crisis and Islamic finance. Thunderbird International Business Review, 53: 551-564.

[12] Mohamad, S. and Tabatabaei, A., (2008) Islamic Hedging: Gambling or Risk Management? , Islamic Law and Law of the Muslim World Paper No. 08-47; 21st Australasian Finance and Banking Conference 2008 Paper.

[13] Özturk, I. (2008). Global financial crisis highlights benefits of Islamic finance. Retrieved from http://www.todayszaman.com/tzweb/yazarDetay.do?haberno

[14] Salehabadi A., Aram M (2002) Islamic Justification of Derivatives Instruments,

[15] International Journal of Financial Services. Vol 4, No. 3.

[16] Sanep A., Nuradli R. S. M. D. (2006) A Review of Forward, Futures and Options From the Islamic Perspective. From Complexity To Simplicity, Journal of ISEFED. Volume 3.

[17] Schoon, N., (2008) Islamic Finance -An Overview, 
European Business Organization Law Review 9.

[18] Securities Commission (2007), Resolutions of the Securities Commission Shariah Advisory Council, available online at;

[19] http://www.sc.com.my/eng/html/icm/Resolutions_SAC_2nd edition.pdf

[20] Standard \& Poor's (2010), Islamic Finance Outlook 2010, available online

http://www2.standardandpoors.com/spf/pdf/media/Islamic Finance_Outlook_2010.pdf

[21] Rafique, M. (2008). Islamic finance can solve global crisis, says scholar. Arab News. Retrieved from http://archive.arabnews.com/?page $=6 \&$ section $=0 \&$ article $=1$ $09247 \& d=24 \& m=4 \& y=2008$

[22] Uberoi, P. and Evans, N. (2008) Islamic Finance: Profit Rate Swap, available online at http://www.allenovery.com/AOWeb/binaries/47753.PDF

[23] Vandore, E. (2008). Crisis widens appeal of Islamic banking. Retrieved from http://www.thejakartapost.com/news/2008/12/25/crisiswidens-appeal-islamic-finance.html

[24] Vikor, K. S., (2005) Between God and the Sultan: A History of Islamic Law, London, Hurst \& Company. 